\section{Plasma Factor(s) influencing Red Cell Production}

THERE is an accumulating body of evidence of the existence of a humoral substance(s) in the plasma of animals with induced anæmia which stimulates erythropoiesis in recipients'.

We have found that when young adult rats are hypophysectomized by a standard technique (from Hormone Assay Laboratories, Inc., Chicago), erythropoiesis is reduced to a minimum by 10-14 days after the operation as shown by a tenfold reduction in the incorporation of iron-59 into the red cells and by a fivefold reduction in the number of reticulocytes. When this level of erythrocyte production is reached, the administration of plasma $(2 \mathrm{ml}$. daily for three days) from rats made anæmic by repeated bleeding (anæmic plasma) results in a three- to seven-fold increase in the amount of iron-59 taken up by the erythrocytes (Table 1) and in a three- to eight-fold increase in the number of reticulocytes in the recipients. As previously described ${ }^{2}$, the iron-59 solution is injected through the tail vein $2 \mathrm{hr}$. after the last plasma injection; $16 \mathrm{hr}$. later, a $1-\mathrm{ml}$. sample of blood is withdrawn from each rat and the radioactivity is counted in a well-type scintillation counter. No significant change is observed in the incorporation of iron-59 into the red cells of the control hypophysectomized rats given normal plasma or saline under these experimental conditions. The blood volume and red-cell mass of hypophysectomized rats, as determined by chromium-51 studies, remain within normal limits during this initial two-week period. A single intravenous or intraperitoneal injection of $2 \mathrm{ml}$. of anæmic plasma given $24 \mathrm{hr}$. before the injection of iron-59 elicits a significant increase in the incorporation of iron-59 into the red cells of hypophysectomized rats. Two injections of $2 \mathrm{ml}$. each of anæmic plasma from other species (for example, rabbit, dog or human being) evoke a positive erythropoietic response in the hypophysectomized rat. Six or more daily $2-\mathrm{ml}$. injections of normal rat plasma must be given to produce a definite inerease in iron-59 taken up by the red cells of hypophysectomized recipients.

The plasma from hypophysectomized rats subjected to hæmorrhage (hæmatocrit less than 25 per cent) exerts an effect on the uptake of iron-59 in hypophysectomized rats that is comparable with that observed after the administration of anæmic plasma.

At this stage of our investigations we prefor not to debate the question raised by others as to whether there is a specific pituitary factor that has a direct control on erythropoiesis; but it is an established fact that the red-cell mass falls slowly to a new equilibrium-level within a period of two to three months after hypophysectomy ${ }^{3}$.

The simplest explanation for our findings may be summarized as follows: Within a few days after hypophysectomy, an overall reduction occurs in the metabolic processes of the animal. With the reduced metabolic requirement and before the red-cell mass has fallen to its new level of equilibrium, the hypophysectomized animal is more or less comparable to an animal that has been made polycythæmic by redcell transfusion. It may be postulated that, in these circumstances, the production of the plasma factor(s) responsible for maintenance of the steady state of circulating erythrocytes is reduced to a minimum since a plethora of red cells already exists. Thus, there is a situation that in essence is the reverse of Table 1. UPTARE OF IRON-59 BY ERYTHROCYTES OF HYPOPHXSECTOM-
IZED RATS AFTER ADMINISTRATION OF NORMAL OR AN FMIO PIASMA

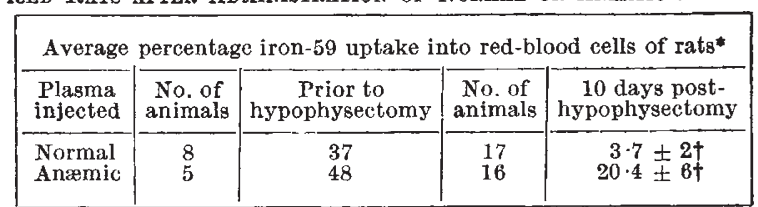

* 16-hr. sample. † Standard deviation of the mean.

Note: While the number of animals prior to hypophysectomy is small, the results are in excellent agreement with those reported on a large number of rats (see ref. 2) when the sampling time was $20 \mathrm{hr}$.

that which obtains when a normal animal is bled. As a consequence, red-cell production is reduced to a minimum. When anæmic plasma is administered under these conditions, there is an exaggerated response in terms of the production of now red cells. As final and complete equilibration of red-cell production and the new reduced red-cell mass slowly become established in the hypophysectomized animal, one finds, as would be expected, that the number of reticulocytes and the uptake of iron-59 have risen from the low values found shortly after hypophys. ectomy to values that are consistent with the new steady state. As reported by others ${ }^{4}$, we have found that producing a polycythæmia in normal animals (mice, rat, rabbit) by repeated transfusion of red cells reduces erythrocyte production. The response to anæmic plasma in these polycythæmic animals in terms of the incorporation of iron-59 into the red cells or the increase in reticulocyte values is comparable with that observed in hypophysectomized animals.

We assume for the sake of simplicity that the factors in normal plasma and in the plasma of normal or hypophysectomized animals subjected to bleeding that stimulate erythropoiesis in hypophysectomized and in polycythæmic assay preparations are one and the same. Further study may, however, reveal a somewhat more complicated picture. Nevertheless, with this sensitive assay method, it should be possible to make more rapid progress in determining the source, the identity, and the physiological role of the plasma factor(s) under discussion in conditions of health and disease. Our studies will be published in detail elsewhere.

$$
\begin{aligned}
& \text { L. O. Jacobson } \\
& \text { L. Plzak } \\
& \text { W. FrIed } \\
& \text { E. GoLd WAsser }
\end{aligned}
$$

Argonne Cancer Research Hospital and

Departments of Medicine and Biochemistry, University of Chicago,

Chicago, Illinois. May 14.

${ }^{1}$ Grant, W. C., and Root, W. S., Physiol. Rev., 32, 449 (1952). Erslev, A., Blood, 8, 349 (1953).

a Plzak, L. F', Fried, W., Jacobson, L. O., and Bethard, W. F., $J$. Lab. Clin. Med., 46, 671 (1955).

$\checkmark$ Van Dyke, D. C., Contopoulos, A. N., Williams, B. S., Simpson, M. E., Lawrence, J. H., and Evans, H. M., Acta Haematologica, 11, 203 (1954).

4 Rohertson, O. H., J. Exp. Med., 26, 221 (1917).

\section{Embryology, Epigenetics and Biogenetics}

IN his stimulating review of Prof. C. H. Waddington's "Principles of Embryology", Dr. Julian Huxley" expresses the hope that Prof. Waddington will write a sequel, and, following his earlier impulse, call it "Principles of Epigenetics". While the term "embryo. logy' suggests a field far more restricted than that which this department of science is now concerned 